\title{
THE IMPACT OF MIDDLE MANAGERS IN CHANGE MANAGEMENT IN THE SERBIAN METAL PROCESSING INDUSTRY
}

\author{
UDC: 005.332.3:669 \\ Original Scientific Paper \\ Jesa KREINER ${ }^{1}$, Milomir STANKOVIĆ ${ }^{2}$, Dragana SAJFERT ${ }^{3}$, \\ Edit TEREK ${ }^{4}$, Zoran Škrinjarić 5 \\ ${ }^{1}$ California State University, 800 N State College Blvd, Fullerton, CA 92831, USA \\ E-mail: jesakreiner@sbcglobal.net \\ ${ }^{2}$ Higher School of Business and Technical Science, Doboj, Ozrenskih Serbian Brigade, No. 5A 74000, \\ Bosnia and Herzegovina \\ ${ }^{3}$ College “Dositej”, 11000 Belgrade, Nusiceva Street 12a, Republic of Serbia \\ Edit Terek* \\ ${ }^{4}$ University of Novi Sad, Technical faculty "Mihajlo Pupin” in Zrenjanin, 23000 Zrenjanin, Đure Đakovića bb, \\ Republic of Serbia \\ Zoran Škrinjarić \\ ${ }^{5}$ University Josip Juraj Strossmayer of Osijek, Fakulty of Food Tehnology, 31000 Osijek, Franje Kuhača 20, \\ Republic of Croatia
}

Paper received: 30.05.2018.; Paper accepted: 15.06.2018.

\begin{abstract}
The research was conducted in the metal processing industry of the Republic of Serbia in the period between June 2011 and December 2014. In particular, the study involves the examination of the impact of middle managers in managing design changes in the metal industry in Serbia. The data was obtained by interviewing 103 middle level managers from 10 companies of metal industry from Zrenjanin, Belgrade, Valjevo and Čačak. The method of statistical data processing was performed using factor analysis. The answers to the questions were given by middle managers who deal with industrial design. The main conclusions of the study are: variables serial production, product design, modern production methods, product assembly make factor 1. Variables environmental impact, energy use, recycling and transmission of noise make the factor 2 . Variables the life of the structure, tolerance of elements, and comfort of the product make the factor 3. Variable capacity and rigidity of the construction make factor 4. Variables exploitation of products and maintenance make the factor 5. Variables functionality of the product and assembly of the product make the factor 6 . Variables technique of network planning and linear programming make factor 7. Variable capacity of the machine and capacity of the factory make the factor 8 . These factors will have an impact on design management in the near future, and make the key to survival in the global market for all companies in the field of mechanical engineering and material handling.
\end{abstract}

Keywords: Design, Production management, Change management, Metal processing.

\section{INTRODUCTION}

According to Certo and Certo (2008) changing the existing organization's process is to increase organizational efficiency. This is when the organization meets its goals. Zimmermann (1995) states that organizations encourage new technologies, expansions of global business policies and organizational modernization trend, and so almost all organizations change in some way. According to Kanter (1989) change is really one of the foundations of the organization and managers are highly appreciated when making changes in various organizational issues. Balistracci (2003) suggested that perhaps the most important factor that a manager must consider when changing the organization is the matter who will be the agent of change - an individual within or outside the organization who is trying to change the existing organizational situation.

According to Gerbec (2017) besides the "pure" 
technical and technology related changes that occur whenever there is a need or motivation, the organizational changes also occur. Managers should define what changes need to be made and see how those changes can take place in a company. There are always some changes needed in order to reduce variability, cut costs, reduce the time required, or reduce turnover, etc. Once every job in a company is defined in terms of the changes to be made (both large and small), constant improvement can become the routine. Innovations bring lessons that inform ongoing operations (Schaffer, 2017). Kotter (1996) in his study states that if we had told a typical group of managers in 1960, over the course of eighteen to thirty-six months, would be trying to increase productivity by 20 to 50 percent, improve quality by 30 to 100 percent, and reduce new-product development times by 30 to 80 percent, they would have laughed at us.

Every day we are witnessing that companies from Serbia, especially in the field of metal processing industries, hardly survive in the open world market. The reason for this, among other things, is the political, economic and scientific development of the country. If we observe the development only in metal processing industry, it can be concluded, based on the available literature, above all, that in Serbia very little modern methods of product development, new production technology, maintenance, control and recycling is applied. In most cases, in the Republic of Serbia manufacturing and product development is still taking place in the way in which it does not give importance to environmental protection, energy saving and all available resources. The tendency of the Republic of Serbia joining the European Union in the latest time, contributed to the improvement of some segments of the technology of the production process, but we believe that it is still not enough for the survival of enterprises of engineering industry in the market and the ability to produce competitive products.

Changes in industrial design is one of the modern methods in the metal industry, which aims primarily to change the design of mechanical systems, which has a direct impact on reducing the use of energy and resources, and environmental protection. The conditions in companies in Serbia (production and services) are such, that they operate and to facilitate management of these processes with the aim of achieving business excellence (Ćoćkalo, Djordjevic, \& Sajfert, 2011).
The world community began to replace the traditional quality control approaches with progressive quality and continuous improvement approaches (Elshennawy, 2004).

A group of authors have represented a research dealing peripherally the ways of increasing reliability of new products (Swan \& Pitta, 2006; Brun, Saetre, \& Gjelsvik, 2009). This method of product development can find its application in the metal industry in Serbia. Through the paper it will be presented the basic principles of the application, the strategy of implementation of design changes, as well as elements used in mechanical engineering, which will be represented using multiple methods for design changes.

Design changes occur as a result of the need for sustainable design and product development, as well as to the need for adequate selection of materials. In this way, there may be a reduction in mass, the individual machine elements, and the overall construction, and thus the complete utilization of a new product. Changes in the design of mechanical products in this way many experts consider as a key technology in terms of competitiveness on the world market in the metalworking industry in general. It is very important for the specialists in the metal processing industry of Serbia to cooperate and ensure the expansion of design change implementation, (Schmid \& Loogen, 2012).

When we talk about design changes in the metal industry and consideration of materials that are applied, it should be taken into account other segments related to product development. The constructions of certain elements have more functions. While loading constructions it is necessary to avoid heavy materials and put them only where they are necessary. New materials should be used such as metals, plastics, and composite. It should be taken into account the anthropometric vehicle cabin, so it can be used by the minimum height of women and a maximum height of men, to save space and minimize material consumption in the specific case of the seat utility vehicle. Ergonomic adaptation of the interior space of a passenger vehicle does not necessarily include adapting a certain range of anthropometric measurements, such as the measurements from the 5th-percentile woman to the 95th-percentile man, (Klarin, Spasojević-Brkić, Sajfert, Đorđević, Nikolić, \& Coćkalo, 2011). 


\section{DEFINING, AREAS AND IMPLEMEN- TATION OF DESIGN CHANGES}

The main purpose and objective of production is the existence or growth of the company and to please the needs of the people. The instrument that needs to maintain production and to meet individual and social needs - is the product. Such a product must create a design, and so on with its quality being the maximum possible extent accepted by consumers. Tomas Maldonado, theorist of functional design provides a definition of the design (Maldonado, 2012) that states that design is a creative activity that consists of defining clear properties of the objects sought to be produced industrially.

The concept of design changes is defined by different research authors, who have the problem of relief structures (Burkardt \& Majić, 2013) approached in different ways, or in the construction of the space in the driver's car cabin (Klarin, Spasojević-Brkić, Sajfert, Žunjić, \& Nikolic, 2009). Changing the design has the task to reduce the weight of technical constructions:

- so as to distribute the load evenly and generally throughout the construction, using permissible voltage, in order to create the possibility of obtaining construction of high strength and load capacity, (Schapitz, 1968),

- so that this does not endanger the capacity and other features of the structure, (Wiedermann, 2007),

- as anthropometric limitations on the construction of passenger cars, (Klarin, SpasojevićBrkić, Stanojević, \& Sajfert, 2008).

\section{APPLICATION OF DESIGN CHANGES IN THE METAL PROCESSING INDUSTRY IN SERBIA}

Effects of weight reduction elements in the metal industry are reflected primarily in the fact that increases the capacity and speed of start-mass element equipment, reduces energy consumption and rolling resistance and acceleration. The lack of these materials is because of their high price compared to steel.

A general hypothesis in this paper, GH: There are basic principles and rules of application of design management in the metal processing industry. (The General hypothesis will be confirmed or disproved by the share in the total sample of companies in the metal industry and on the basis of their different dimensions to identify the factors affecting the design).

Auxiliary hypothesis H1: The greater the impact of design in the metal processing industry, the greater is the influences in changing business.

\section{METHOD}

The study of influence of middle-level managers to manage design changes in the metal industry in Serbia was measured by factor analysis. Factor analysis is an instrument that aims to assist in the understanding of the necessary prerequisites and consequences of change management. The instrument evaluation was rated from 1 to 5 , where 1 is strongly disagree, and 5 is completely agree. This method of statistical analysis of the data was used in order to obtain as complete and accurate results. The questionnaire itself is concise and is used in research dealing with the behavior of employees. The questionnaire has 21 items that evaluate the attitudes of middle-level managers on change management and design aspects of the job: mass production, design production, modern production methods, product assembly, environmental impact, energy use, recycling, noise transfer lifespan construction tolerance, comfort, capacity, rigidity, exploitation of the product, maintenance, product functionality, product assembly, network planning techniques, linear programming, capacity machines, and the factory's capacity. The survey was conducted by the respondents (middle level managemers) who completed the questionnaire. The survey was conducted using interviews with respondents. A total of $\mathrm{N}=103$ middle managers from 10 companies completed questionnaire.

\section{RESULTS AND DISCUSSION}

In this paper, we used factor analysis, which consists of a set of mathematical and statistical methods that allow a greater number of variables, among which there is a connection that establishes a small number of variables that explain this relationship, in our case the change of product design in the metal industry in Serbia.

Factor analysis, a multivariate technique in this paper has had two objectives: to identify and understand the basic ideas and common features for multiple variables, and reducing the excessive number of variables in the design of products. 
Featured latent variables (factors) are considered sources (generators) variation and co-variation among manifest variables. If the variable has a great factor loading only one factor and not the other, then it is easy to identify this factor.

After principal component analysis, factor analysis begins to "rotate" components. The aim is to redefine and clarify the meaning of each of the factors. The process goes down to a redistribution of influence factors with the first principal component to the other, so that the total variance that is explained through factors is evenly distributed between components.

The performed factor analysis in this case has the following characteristics:

- Factor analysis is based on principal component analysis as a method of extracting factors;

- The analysis selected 8 factors as the maximum number of factors that are optimal in the study;

- The minimum eigenvalue is 1 , which is the usual height variance of major components;

- After the first extraction of factors their rotation was carried out by varimax normalized method. It is the best known method for the rotation of factors. Rotation is done to factors that were easier to interpret.

Eight factors together explained $39.5 \%$ of the variation of the original data, which can be considered satisfactory in the given model. The analysis used Scree criterion. Based on this criterion, the number of important factors is determined on the basis of determining factors after which the values of characteristic roots are established. In figure 1, on the horizontal axis, there are factors that indicate eigenvalues of each factor. Based on the pictures the breakpoints help to determine how many factors should be taken into account in the analysis. The figure shows that the first factor is more important than others.

On this basis, the first factor explains the largest part of the variance and covers approximately $7.54 \%$ of the variation of the original data. After the first factor, the values continuously decrease until the tenth, after which the values are established. Next eigenvalues for eventual ninth factor is less than 0.8 , and it can be concluded that the addition of new factors does not contribute significantly to understanding the model.
The analysis of the 8 factors was made because the aspect of this particular research provides understandable information and clearer grouping of variables given whit 8 factors.

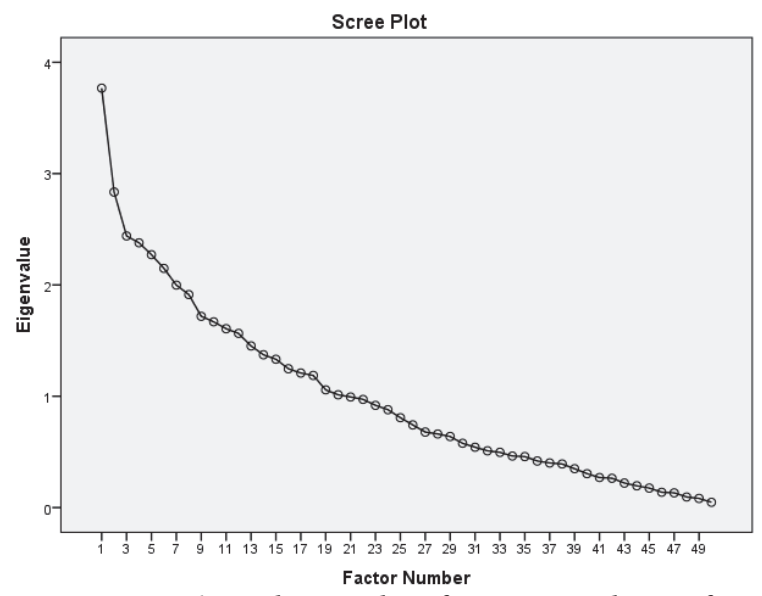

Figure 1: Relationship factors - values of characteristic roots

Table 1 shows the eigenvalues for models with one, two, three and up to eight-factors. The same table in the last column shows how the growing proportions of the explained variance is increasing the number of factors.

Table 1: Distribution of eigenvalues according to different models of factor analysis

\begin{tabular}{|c|c|c|c|}
\hline \multicolumn{4}{|c|}{ Initial Eigenvalues } \\
\hline Factor & Total & $\begin{array}{c}\text { \% of } \\
\text { Variance }\end{array}$ & $\begin{array}{c}\text { Cumulative } \\
\text { \% }\end{array}$ \\
\hline 1 & 3.768 & 7.536 & 7.536 \\
\hline 2 & 2.834 & 5.669 & 13.204 \\
\hline 3 & 2.440 & 4.880 & 18.085 \\
\hline 4 & 2.378 & 4.757 & 22.842 \\
\hline 5 & 2.272 & 4.543 & 27.385 \\
\hline 6 & 2.149 & 4.297 & 31.862 \\
\hline 7 & 1.998 & 3.997 & 35.679 \\
\hline 8 & 1.913 & 3.827 & 38.505 \\
\hline
\end{tabular}

Table 2 shows the factor loadings and correlation coefficients of the original variables with the obtained factors. The identified factors should be interpreted on the basis of these results. The table below shows factor loadings that are most important, and which is higher than 0.4. Thus, for example, it can be seen that the factor 1 is significant for the variables of the original 4 and so on. The negative sign in the factor analysis is of no great significance because it is a multi-dimensional rather than two-dimensional space. 
Table 2: Correlation coefficients of variables (parameters) with a given factor

\begin{tabular}{|c|c|c|c|c|c|c|c|c|}
\hline & \multicolumn{8}{|c|}{ Factor } \\
\hline & 1 & 2 & 3 & 4 & 5 & 6 & 7 & 8 \\
\hline Serial production & 940 & & & & & & & \\
\hline Production design & .932 & & & & & & & \\
\hline Modern production methods & -.882 & & & & & & & \\
\hline Mass production & .614 & & & & & & & \\
\hline Environmental impact & & .602 & & & & & & \\
\hline Energy use & & .482 & & & & & & \\
\hline Recycling & & .483 & & & & & & \\
\hline Noise transmission & & .447 & & & & & & \\
\hline The life of the structure & & & .608 & & & & & \\
\hline Tolerance of elements & & & .465 & & & & & \\
\hline Comfort of the product & & & .411 & & & & & \\
\hline Capacity & & & & .418 & & & & \\
\hline Rigidity of the construction & & & & -.402 & & & & \\
\hline Exploitation of products & & & & & .588 & & & \\
\hline Maintenance & & & & & -.418 & & & \\
\hline Functionality of products & & & & & & .525 & & \\
\hline Assembly of products & & & & & & .425 & & \\
\hline Techniques of network planing & & & & & & & .524 & \\
\hline Linear Programming & & & & & & & .503 & \\
\hline Machine capacity & & & & & & & & -.673 \\
\hline Capacity of the factory & & & & & & & & .430 \\
\hline
\end{tabular}

On the basis of Table 2 certain variables have been brought together. For example, variables "Serial production", "Product design", "Modern production methods", "Product assembly" behave in the same way and they characterize the first factor (Factor 1). Variables "Environmental impact", "Energy use", "Recycling" and "Transmission of noise" behave in the same way and they characterize the second factor (Factor 2). Variables "The life of the structure", "Tolerance of elements "and "Comfort of the product" behave in the same way and they characterize the third factor (Factor 3). The variable "Capacity" and "Rigidity of the construction" behave in the same way and they characterize the fourth factor (Factor 4). Variables "Exploitation of products", "Maintenance" behaves in the same way and they characterize the fifth factor (Factor 5). Variables "Functionality of the product" and "Assembly of products" behave in the same way and they characterize the sixth factor (Factor 6). Variables "Technique of network planning" and "Linear Programming" behave in the same way and they characterize seventh factor (Factor 7). Variables "Machine capacity" and "Capacity of the factory" behave in the same way so they characterize factor 8 (Factor 8).
By grouping variables there was an attempt to create independent factors (extracted group of new factors F1, F2, F3, F4, F5, F6, F7 and F8). Featured factors are the result of the discrimination analysis, which basically represents a discriminant function that is well designed.

Table 3 shows the factor scores obtained with the normal schedule. If they have a custom that means that in a reliable grouped manner they can manage design changes in the metal industry in Serbia. The The results of tests of normality are shown in the table. There were applied two tests: the Kolmogorov-Smirnov test for normality and Lilliefors. If the value of the field "Skewness" and "Kurtosis" is approximate to zero, it means that it has a good adaptation.

When using the Kolmogorov - Smirnov test for normality (Table 4), the conclusion is that there is a good adaptation. Adjustment is good if the value of sigma (significance value) is bigger than 0.05 . 
J. Kreiner The impact of middle managers in change management in

et al. the Serbian metal processing industry

Table 3: Factor scores

\begin{tabular}{|c|c|c|c|}
\hline & & Statistic & St. Error \\
\hline \multirow[t]{12}{*}{ Serial production } & Mean & 2,39 & .098 \\
\hline & $\begin{array}{l}95 \% \text { Confidence Interval Lower Bound } \\
\text { for Mean Upper Bound }\end{array}$ & $\begin{array}{l}2,19 \\
2,58\end{array}$ & \\
\hline & $5 \%$ Trimmed Mean & 2,38 & \\
\hline & Median & 3.00 & \\
\hline & Variance & ,985 & \\
\hline & Std. Derivation & ,992 & \\
\hline & Minimum & 1 & \\
\hline & Maximum & 4 & \\
\hline & Range & 3 & \\
\hline & Interquartile Range & 2 & \\
\hline & Skewness &,- 297 & .238 \\
\hline & Kurtosis & $-1,205$ & .472 \\
\hline \multirow[t]{12}{*}{ Production design } & Mean & 3.22 & .193 \\
\hline & $\begin{array}{l}95 \% \text { Confidence Interval Lower Bound } \\
\text { for Mean Upper Bound }\end{array}$ & $\begin{array}{l}2.84 \\
3.61\end{array}$ & \\
\hline & $5 \%$ Trimmed Mean & 3.14 & \\
\hline & Median & 3.00 & \\
\hline & Variance & 3.82 & \\
\hline & Std. Derivation & 1.95 & \\
\hline & Minimum & 1 & \\
\hline & Maximum & 7 & \\
\hline & Range & 6 & \\
\hline & Interquartile Range & 4 & \\
\hline & Skewness & .483 & .238 \\
\hline & Kurtosis & -.952 & .472 \\
\hline \multirow[t]{12}{*}{ Modern product. methods } & Mean & 2.77 & .095 \\
\hline & $\begin{array}{l}95 \% \text { Confidence Intrval Lower Bound } \\
\text { for Mean Upper Bound }\end{array}$ & $\begin{array}{l}2.58 \\
2.96\end{array}$ & \\
\hline & 5\% Trimmed Mean & 2.80 & \\
\hline & Median & 3.00 & \\
\hline & Variance & .926 & \\
\hline & Std. Derivation & 1 & \\
\hline & Minimum & 4 & \\
\hline & Maximum & 3 & \\
\hline & Range & 2 & \\
\hline & Interquartile Range & -.053 & .238 \\
\hline & Skewness & -1.141 & .472 \\
\hline & Kurtosis & 2.54 & .097 \\
\hline \multirow[t]{12}{*}{ Assembly production } & Mean & & \\
\hline & $\begin{array}{l}95 \% \text { Confidence Intrval Lower Bound } \\
\text { for Mean Upper Bound }\end{array}$ & $\begin{array}{l}2.35 \\
2.74\end{array}$ & \\
\hline & 5\% Trimmed Mean & 2.55 & \\
\hline & Median & 3.00 & \\
\hline & Variance & .976 & \\
\hline & Std. Derivation & .988 & \\
\hline & Minimum & 1 & \\
\hline & Maximum & 4 & \\
\hline & Range & 3 & \\
\hline & Interquartile Range & 1 & \\
\hline & Skewness & -.279 & .238 \\
\hline & Kurtosis & -.962 & .472 \\
\hline
\end{tabular}

Table 4: Tests of Normality

\begin{tabular}{|l|c|c|c|c|c|c|}
\hline \multirow{2}{*}{} & \multicolumn{2}{|c|}{ Kolmogorov - Smirnov } & \multicolumn{4}{c|}{ Shapiro - Wilk } \\
\cline { 2 - 7 } & Statistic & df & Sig. & Statistic & df & Sig. \\
\hline Modern prod. methods & .157 & 103 & .000 & .891 & 103 & .000 \\
\hline
\end{tabular}


Figure 2 below shows the histogram of the frequency of the variable "Design production."

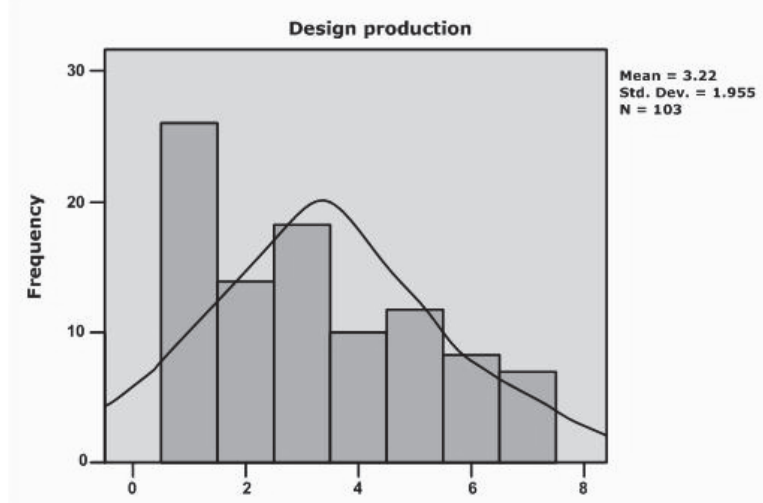

Figure2: Histogram of the frequency of the variable "design production"

Within the analysis there were selected 8 factors and that is the maximum number of factors that are optimal according to the study. Factor analysis shows a relatively high average grade, so these results can be interpreted as a legacy of socialist times, which always strives for equality. Mediumlevel managers, based on the research are aware that employees in Serbia, due to habits of past times, highly appreciate the attributes of mass production, design production, modern production methods and so on. All this is due to the low living standards and low wages of employees in the metal processing industry in Serbia.

\section{CONCLUSION}

Management of design changes in the metal industry in Serbia is possible using the factor analysis that gave us these variables. Through this work the basic principles and rules of application of design management in the metal industry in Serbia is presented. The general and auxiliary hypothesis have been proved. Operation using factor analysis gives answers to the question what are the goals and what are the strategies of management application to design using factor analysis. The paper shows that these segments are used for managing the design as well as how to properly choose the proper procedures and that the result is not only the principle of design management, but also that it is implemented in production processes.

\section{REFERENCES}

Balistracci, D. (2003). Be a Change Agent. Quality Progress, 36, 65.
Brun, E., Saetre, A. S., \& Gjelsvik, M. (2009). Classification of ambiguity in new product development project. European Journal of Innovation Management, 12(1), 62-85.

Burkardt, N., \& Majić, N. (2013). Konstruktiver Leichtbau. Karlsruher: KIT - Karlsruher Institut gur Tehnologie.

Certo, S.S., \& Certo, T.S. (2008). Modern management. Zagreb: Zagreb School of Economics and Management, Mate.

Ćoćkalo, D., Đorđević, D., \& Sajfert, Z., (2011). Elements of the model for customer satisfaction: Serbian economy research. Total Quality Management, 22(8), 807-832.

Elchennawy, A. K. (2004). Quality in the new age and the body of knowledge for quality engineers. Total Quality Management, 15(5-6), 603-614.

Gerbec, M. (2017). Safety change management - A new method for integrated management of organizational and technical changes. Safety Science, 100(B), 225234.

Kanter, R. M. (1989). The New Managerial Work. Harvard Business Review, 67(6), 85-92.

Klarin, M., M., Spasojević-Brkić, K. V., Sajfert, D. Z., Žunjić, G. A., \& Nikolić, S. M. (2009).

Determination of passenger car interior space for foot controls accommodation. Proc. IMechE, Part D: J. Automobile Engineering, 223 (12), 1529-1547.

Klarin, M., M., Spasojević-Brkić, K. V., Stanojević, P., \& Sajfert, D. Z., (2008). Anthropometrical limitations in the construction of passenger vehicles: case study. Proc. IMechE, Part D: J. Automobile Engineering, 222(8), 1409-1419.

Klarin, M., M., Spasojević-Brkić, V. K., Sajfert, Z. D., Đorđević, D. B., Nikolić, M. S., \& Ćoćkalo, D. Z. (2011). Determining the width of the optimal space needed to accommodate the drivers of passenger vehicles using the analogy of anthropometric measurement dynamics and mechanical mechanisms. Proc. IMechE, Part D: J. Automobile Engineering, 225(4), 425-440.

Kotter, J. P. (1996). Leading Change. Boston, Massachusetts: Harvard Business School Press.

Maldonado, T. (2012). Design and new industrial perspectives [in Croatian]. In Vukić, F. (Ed.), Teorija povijesti dizajna: kritička antologija (pp. 235-240). Zagreb: Golden marketing - Tehnička knjiga.

Schaffer, R H. (2017). All Management Is Change Management. Harvard Business Review Digital Articles. 10/26/2017, p 2-4.

Schapitz, E. (1968). Ingenieur und Tehnologe: Grundlagen f. e. Dialog uber d. geistige Existenz in d. techenischen Welt. Wurzburg: Werkbund-Verlag.

Schmid, N., \& Loogen, F. (2012). Leichtbau in Mobilitat und Fertigung. Stuttgart: Universidad Stuttgart.

Swan, H., \& Pitta, D. (2006). Innovations in new product development at universal pipe and fittings. 
Journal of Product \& Brand Management, 15(2), 150-154.

Wiedermann, J. (2007). Autopoetic automata: Compatibility in Amorphos stuctures. Berlin:

Springer, 781-790.
Zimmermann, J. (1995). The principles of managing change. HR Focus, 2, 15-16.

\section{UTICAJ SREDNJIH MENADŽERA KOD UPRAVLJANJA PROMENAMA U METALOPRERAĐIVAČKOJ INDUSTRIJI SRBIJE}

U radu su prikazani rezultati istraživanja uticaja srednjih menadžera pri upravljanju promenama u metaloprerađivačkoj industriji u Republici Srbiji. Istraživanje je sprovedeno u metaloprerađivačkoj industriji u Republici Srbiji u periodu od juna 2011. do decembra 2014. godine. Podaci su dobijeni anketiranjem 103 menadžera srednjeg nivoa iz 10 kompanija iz metaloprerađivačke industrije Zrenjanina, Beograda, Valjeva i Čačka. Statistička metoda za obradu podataka je izvršena korišćenjem faktorske analize. Odgovore na pitanja dali su srednji menadžeri koji se bave industrijskim dizajnom. Glavni zaključci istraživanja su: varijable serijska proizvodnja, dizajn proizvoda, savremene metode proizvodnje i faktor proizvodnje čine faktor 1; Varijable uticaj na životnu sredinu, korištenje energije, recikliranje i prenos buke čine faktor 2; Varijable životni vek strukture, tolerancija elemenata i komfor proizvoda čine faktor 3; Varijable kapacitet i rigidnost konstrukcije čine faktor 4; Varijable eksploatacija proizvoda i održavanje čine faktor 5; Varijable funkcionalnost proizvoda i montaža proizvoda čine faktor 6; Varijable tehnika planiranja i linearnog programiranja čine faktor 7; Varijable kapacitet mašine i kapacitet fabrike čine faktor 8. Ovi faktori će uticati na upravljanje projektovanjem u bliskoj budućnosti i biće ključni za sve kompanije koje žele da opstanu na globalnom tržištu iz oblasti koje su vezane za meteloprerađivačku industriju i mašinstvo.

Ključne reči: Dizajn, Upravljanje proizvodnjom, Upravljanje promenama, Obrada metala. 